\title{
Detection and prevalence of multidrug-resistant Klebsiella pneumoniae strains isolated from poultry farms in Blitar, Indonesia
}

\author{
DIAN AYU PERMATASARI ${ }^{1}$, ADIANA MUTAMSARI WITANINGRUM ${ }^{1}$, FRESHINTA JELLIA WIBISONO ${ }^{2}$, \\ MUSTOFA HELMI EFFENDI, ${ }^{1,4}$ \\ ${ }^{1}$ Department of Veterinary Public Health, Faculty of Veterinary Medicine, Universitas Airlangga, Jl. Raya Mulyorejo, Surabaya 60115, East Java, \\ Indonesia. \\ ${ }^{2}$ Department of Veterinary Public Health, Faculty of Veterinary Medicine, Universitas Wijaya Kusuma Surabaya. Jl. Dukuh Kupang XXV No. 54, \\ Surabaya 60225, East Java, Indonesia \\ ${ }^{3}$ Halal Research Center, Universitas Airlangga, Jl. Raya Mulyorejo, Surabaya 60115, East Java, Indonesia. Tel./fax.: +62-31-5915551, \\ vemail: mheffendi@yahoo.com
}

Manuscript received: 31 August 2020. Revision accepted: 16 September 2020.

\begin{abstract}
Permatasari DA, Witaningrum AM, Wibisono FJ, Effendi MH. 2020. Detection and prevalence of multidrug-resistant Klebsiella pneumoniae strain isolated from poultry farms in Blitar, Indonesia. Biodiversitas 21: 4642-4647. Antibiotics are commonly used as therapy and disease control in humans and animals. However, the widespread use of antibiotics may also trigger the rise of antibiotic resistance. Therefore, the aim of this study was to study the occurrence of Multidrug-Resistant (MDR) of Klebsiella pneumoniae from poultry farms in Blitar. Chicken cloacal swabs from 63 poultry farms ( 32 broilers and 31 layers) were taken randomly, using total samples 160 broilers and 155 layers. The collected swab samples were inoculated on MacConkey agar medium for isolation and identification. Single colony was isolated after primary positive cultures and identified by using the IMViC test and TSIA. 28 (8.88\%) out of samples were found positive for Klebsiella pneumoniae. The antimicrobial confirmation test showed that $53.57 \%$ of the $K$. pneumoniae isolates were Multi-Drug Resistance (MDR) bacteria. The percentage of MDR bacteria against different antibiotics included ampicillin $75 \%$, Erythromycin $42.86 \%$, Tetracycline $35.72 \%$, Sulfamethoxazole $32.14 \%$ and Streptomycin $21.4 \%$. This study confirmed that the percentage of resistant isolates of Klebsiella pneumoniae from 5 antimicrobial agents of broiler chicken are higher than layer chicken. The presence of multidrug-resistant bacteria is a threat to public health and livestock. The impact of these conditions leaves a limited treatment option as chicken farmers in Indonesia still using antibiotics without veterinarian supervision.
\end{abstract}

Keywords: Antibiotic resistance, Klebsiella pneumoniae, MDR, poultry farms, public health

\section{INTRODUCTION}

Antibiotics are commonly used as therapy and to control microbial infections in humans and animals. However, the widespread use of an antibiotic may trigger the rise of antibiotic resistance not only in humans but in animals also (Kempf et al. 2015; Hayati et al. 2019). The European Centre for Disease Prevention and Control/ European Food Safety Authority/European Medicines Agency (ECDC/EFSA/EMA) joint report in 2014 stated that the average antibiotic consumption in animals (152 $\mathrm{mg} / \mathrm{kg}$ ) was higher than in humans $(124 \mathrm{mg} / \mathrm{kg})$. It is estimated that two-thirds of antimicrobials produced globally are consumed in the livestock and poultry (CDDEP 2015). The raising small-scale commercial poultry farms (PFs) demands low investment, it has been expanding at a high rate, mostly in the rural and semi-urban areas which contribute to national economic growth, considerably. These PFs are often run by unskilled, nonprofessional managers having poor knowledge of biosecurity alike other developing countries (Conan 2012). Since most of these poultry farms neither do have good surveillance systems nor well-documented monitoring mechanisms to record potential pathogenic microorganisms or other poultry-hazards claiming serious public health implications (Nahar et al. 2014). The increase in the prevalence of infections caused by multidrug-resistant (MDR) bacteria belonging to the Enterobacteriaceae group poses a great concern since these are common natural inhabitants of microbiome (Navon-Venezia et al. 2017).

Klebsiella pneumoniae is a Gram-negative, rod-shaped, non-motile, encapsulated opportunistic pathogen. This bacterium is part of the Enterobacteriaceae family, facultative anaerobe with the mucoid colony (Fielding et al. 2012; Al-Ammiri et al. 2016). The increase of multidrug resistance in Gram-negative bacteria is now a serious challenge (Exner et al. 2017). Five factors have been proposed for Klebsiella pathogenesis, including capsular antigen (as the most important virulence factor in $K$. pneumoniae), adhesives, lipopolysaccharide, siderophore (Struve et al. 2009). Cases of multidrug resistance (MDR) have been reported in K. pneumoniae isolates against more than three types of antibiotics (Hayati et al. 2019). Notably, the prevalence of antibiotic resistance is increasing among Enterobacteriaceae, including $K$. pneumoniae strains isolated from animals (Davis and Price 2016). Due to the extensive use of antibiotics in humans, veterinary medicine, and agricultural practice during the last few decades, the emergence of $K$. pneumoniae strains that harbor various resistance genes has increased 
considerably $K$. pneumoniae has acquired increasingly high levels of antimicrobial drug resistance (Wu et al. 2019).

Antimicrobial resistance is often caused by overuse of antibiotics in human and animal medicine and has now emerged as a global health problem (Pitout and Laupland 2008; Widodo et al. 2020). The resistance of microorganisms to antimicrobial drugs that are initially sensitive is called antimicrobial resistance (AMR). This is a natural process and is facilitated by excessive antimicrobial abuse (Riwu et al. 2020). Gram-negative bacteria have developed this resistance by developing enzymes that can destroy antibiotics, by having resistant metabolic pathways, and by changing receptors for antimicrobial agents (Okonko et al. 2009; Wibisono et al. 2020). K. pneumoniae has two types of antibiotic resistance mechanisms. One mechanism involves the expression of ESBL, which develops resistance in bacteria to cephalosporins and monobactams. The second mechanism involves carbapenemase expression, which helps develop resistance to all available $\beta$-lactams (Riwu et al. 2020). The presence of the Extended Spectrum Beta-Lactamase (ESBL) gene consisting of SHV, TEM, and CTX-M encoded by plasmids in $K$. pneumoniae has an impact on resistance to different antibiotics (Ahmed et al. 2014). Klebsiella spp has also developed antimicrobial resistance, which is an alarming situation in the field of human medicine (Lynch et al. 2013). This antimicrobial treatment failure is safe for humans and animals (Guardabassi et al. 2004).

Antibiotic sensitivity of $K$. pneumoniae has not been well studied, especially in poultry. The use of antimicrobials in broiler chickens was higher than that of laying hens, this was due to maintaining the speed of body weight growth of broilers. Whereas in laying hens there are fewer antimicrobials just to maintain egg production (Wibisono et al. 2020). Given the differences between the types, it is necessary to understand how the incidence of resistance varies in order to precisely provide the policies in which they will have the greatest impact (Brower et al. 2017). The aim of this study was to study the occurrence of Multidrug-Resistant (MDR) isolates of Klebsiella pneumoniae from poultry farms in Blitar.

\section{MATERIALS AND METHODS}

\section{Research design, location, and sampling}

This cross-sectional study was done in May-June 2019. Chicken cloacal swabs were collected randomly from 63 poultry farms in Blitar (31 layers and 32 broilers) with total of 160 cloacal swabs of broilers and 155 cloacal swabs of layers. The cloacal swabs were transferred by using transport swabs in Amies transport medium from Biomedics-Madrid, Spain (Vasilakopoulou et al. 2020), and carrying by the cooler box to the laboratory for bacterial isolation and identification.

\section{Isolation and identification of Klebsiella pneumoniae}

Samples were brought to the laboratory for the isolation and identification of $K$. pneumoniae bacteria. Isolated colony of bacteria was identified as Klebsiella pneumoniae based on Gram's staining, colony character on selective MacConkey Agar media from Oxoid-England incubated at $35-37^{\circ} \mathrm{C}$ for $20-24 \mathrm{hrs}$ (Effendi et al. 2018). Single colonies were isolated after primary positive cultures and identified by using the IMViC test (Indol-Motility, Methyl Red, Voges Proskauer, Citrate) and Triple Sugar Iron Agar (TSIA) (Arya et al. 2020).

\section{Antibiotic sensitivity confirmation test}

All Isolated $K$. pneumoniae bacteria were tested for their sensitivity to antibiotics with the disc diffusion test by Kirby-Bauer method on Mueller-Hinton Agar MerckGermany (Effendi et al. 2019). All disks used in the disc diffusion test were obtained from Oxoid, England, in the following concentrations: Ampicillin (Amp $10 \mu \mathrm{g}$ ), Streptomycin (S $10 \mu \mathrm{g}$ ), Tetracycline (TE $30 \mu \mathrm{g}$ ), Erythromycin (E $2 \mu \mathrm{g}$ ), and Sulfamethoxazole (SXT 25 $\mu \mathrm{g})$. The culture turbidity was adjusted to $0.5 \mathrm{McF}$ arland standard. The sterile cotton swab was dipped into the suspension and spread evenly over the entire MuellerHinton Agar surface (Geta et al. 2019). The antibiotics discs were placed onto the surface of the inoculated plates and incubated at $37^{\circ} \mathrm{C}$ for $16-18 \mathrm{hrs}$. The zone diameters of inhibition were measured in millimeters and interpreted as susceptible, intermediate, and resistant (CLSI 2017). The evaluation of specimens for antibiotic resistance was conducted according to the clinical and laboratory standards institute (CLSI) guidelines (Watts 2013).

\section{RESULTS AND DISCUSSION}

\section{Isolation and identification of Klebsiella pneumoniae}

The result of isolation and identification of 155 samples of cloacal swabs on layer chicken farms showed that 6 (3.87\%); and 160 samples of cloacal swabs on broiler chicken farms showed that $22(13.75 \%)$ isolates were positive of $K$. pneumoniae. The distribution of samples showing positive growth on MacConkey Agar was as follows: 5 samples in Srengat, 2 in Undanawu, 8 in Talun, 3 in Kademangan, 4 in Bakung, 3 in Ponggok, and 3 in Garum. Positive samples of $K$. pneumoniae on MacConkey Agar looks pink with colonies culture looks very mucoid (Masruroh et al. 2016). K. pneumoniae identified with lactose fermentation pink and dome-shaped mucoid colonies (Figure 2) and also confirmed by a biochemical test using IMViC and Triple Sugar Iron Agar. The biochemical test identified lactose fermenter, non-motile, Indole production negative, Voges-Proskauer test positive, Methyl Red negative, Citrate utilization test positive, TSIA acid/ acid with gas (Figure 3 ). In the antibiotic sensitivity test, the positive organism was sensitive to Ampicillin and Streptomycin, while it was resistant to Tetracycline, Erythromycin, and Sulfamethoxazole (Figure 4). The presence of multidrug-resistant (MDR) producing $K$. pneumoniae in layer and broiler chicken farms, shown in Table 1. 
Table 1. Data of multidrug-resistant Klebsiella pneumoniae in poultry farms

\begin{tabular}{|c|c|c|c|c|c|c|c|}
\hline \multirow{2}{*}{ Type of livestock } & \multirow{2}{*}{ Location } & \multirow{2}{*}{ Farms } & \multirow{2}{*}{ Number of samples } & \multicolumn{2}{|c|}{ Klebsiella pneumoniae } & \multicolumn{2}{|c|}{ MDR } \\
\hline & & & & Positive & Percentage & Positive & Percentage \\
\hline \multirow[t]{5}{*}{ Layer } & Srengat & 17 & 85 & 1 & $1.17 \%$ & 0 & $0 \%$ \\
\hline & Udanawu & 6 & 30 & 2 & $6.67 \%$ & 1 & $50 \%$ \\
\hline & Talun & 4 & 20 & 2 & $10 \%$ & 2 & $100 \%$ \\
\hline & Kademangan & 4 & 20 & 1 & $5 \%$ & 0 & $0 \%$ \\
\hline & Sub-total & 31 & 155 & 6 & $3.87 \%$ & 3 & $50 \%$ \\
\hline \multirow[t]{7}{*}{ Broiler } & Srengat & 6 & 30 & 4 & $13 \%$ & 1 & $25 \%$ \\
\hline & Kademangan & 4 & 20 & 2 & $10 \%$ & 1 & $50 \%$ \\
\hline & Bakung & 4 & 20 & 4 & $20 \%$ & 3 & $75 \%$ \\
\hline & Ponggok & 10 & 50 & 3 & $6 \%$ & 2 & $66.67 \%$ \\
\hline & Talun & 4 & 20 & 6 & $30 \%$ & 3 & $50 \%$ \\
\hline & Garum & 4 & 20 & 3 & $15 \%$ & 2 & $66.67 \%$ \\
\hline & Sub-total & 32 & 160 & 22 & $13.75 \%$ & 11 & $50 \%$ \\
\hline Total & & 63 & 315 & 28 & $8.88 \%$ & 15 & $53.57 \%$ \\
\hline
\end{tabular}

Table 2. Antimicrobial resistance pattern of Klebsiella pneumoniae isolates

\begin{tabular}{|c|c|c|c|c|c|c|}
\hline \multirow{2}{*}{$\begin{array}{l}\text { Antimicrobial } \\
\text { agent }\end{array}$} & \multicolumn{2}{|c|}{$\begin{array}{l}\text { Number percentage of } \\
\text { sensitive isolates }\end{array}$} & \multicolumn{2}{|c|}{$\begin{array}{l}\text { Number percentage of } \\
\text { intermediate isolates }\end{array}$} & \multicolumn{2}{|c|}{$\begin{array}{c}\text { Number percentage of resistant } \\
\text { isolates }\end{array}$} \\
\hline & Layer & Broiler & Layer & Broiler & Layer & Broiler \\
\hline Ampicillin & $2(7.14 \%)$ & $0(0 \%)$ & $0(0 \%)$ & $1(3.57 \%)$ & $4(14.29 \%)$ & $21(75 \%)$ \\
\hline Streptomycin & $4(14.29 \%)$ & $14(50 \%)$ & $0(0 \%)$ & $2(7.14 \%)$ & $2(7.14 \%)$ & $6(21.43)$ \\
\hline Erythromycin & $0(0 \%)$ & $6(21.43)$ & $3(10.71 \%)$ & $4(14.29 \%)$ & $3(10.71 \%)$ & $12(42.86 \%)$ \\
\hline Tetracycline & $3(10.71 \%)$ & $11(39.29 \%)$ & $0(0 \%)$ & $1(3.57 \%)$ & $3(10.71 \%)$ & $10(35.71 \%)$ \\
\hline Sulfamethoxazole & $3(10.71 \%)$ & $8(28.57 \%)$ & $0(0 \%)$ & $5(17.86 \%)$ & $3(10.71 \%)$ & $9(32.14 \%)$ \\
\hline
\end{tabular}

\section{Disc diffusion test for antibiotic sensitivity confirmation test}

The number of positive samples from broilers exceeded the one obtained from Layers (11 and 3, respectively). Isolated strains (315) originated from 31 out of the 32 visited farms, i.e., $53.57 \%$ of the farms were positive for multidrug-resistant $K$. pneumoniae. As shown in table 1 , the highest prevalence multidrug-resistant $K$. pneumoniae was detected in Talun whereas, the lowest was detected in Srengat and Kademangan. Percentages of isolates classified as sensitive, intermediate, or resistant were used to summarize resistance prevalence overall and disaggregated by farm (Table 2, Figure 1). A high percentage of $K$. pneumoniae resistant to AMP (75\%), E (42.86\%), TE (35.72\%), SXT (32.14\%), and S (21.4\%) was observed. The degree of resistance to Ampicillin, Erythromycin, Tetracycline, Sulfamethoxazole, and Streptomycin was consistently high levels only in broiler farms.

\section{Discussion}

In this research, the results of biochemical test identified lactose fermenter, non-motile, Indole production negative, Voges-Proskauer test positive, Methyl Red negative, Citrate utilization test positive, TSIA Acid/ Acid with gas. The isolation and identification results were confirmed by $K$. pneumoniae character according to ElMansi et al. (2000) in order to verify that the cured strain was indeed a derivative of $K$. pneumoniae, the IMViC tests were carried out routinely.
The antimicrobial confirmation test showed that $53.57 \%$ of the K. pneumoniae isolates were MDR bacteria. These results corroborate similar studies in broiler productions, but the prevalence reported here is similar or higher (Dierikx et al. 2013; Kar et al. 2015; Laube et al. 2013). Multidrug-resistant cases in K. pneumoniae caused longer treatment and were difficult to cure. The pattern of antibiotic resistance is expected to be a guide in selecting the right antibiotic for treatment. The widespread use of antibiotics without close supervision can lead to antibiotic resistance (Hayati 2019). Until recently, antibiotics were easy to obtain and could be used without veterinary supervision. As many as $72.3 \%$ of chicken farmers in Indonesia still using antibiotics without veterinarian supervision (Arief et al. 2016).

The resistance against ampicillin was $75 \%$, erythromycin $42.86 \%$, tetracycline $35.72 \%$, sulfamethoxazole $32.14 \%$, streptomycin $21.4 \%$. Rashed et al. (2013) and Effendi et al. 2018 reported that Klebsiella spp. showed higher resistance against ampicillin (74\%) and amoxicillin (90\%). This resistance of Klebsiella spp. against amoxicillin was not in accordance with this result. Klebsiella spp. were naturally sensitive or intermediate to penicillin, all tested aminoglycosides, quinolones, tetracyclines, trimethoprim, cotrimoxazole, chloramphenicol, and nitrofurantoin (Stock and Wiedemann 2001). These are used singly or in combination with 2 or more ABs, which has been reported to contribute significantly to the emergence of multidrug-resistant in chicken isolates (McEwen and Fedorka-Cray 2002). 


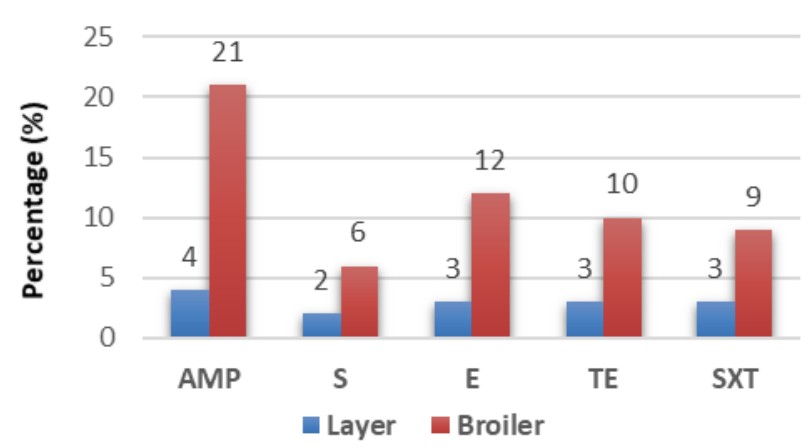

Figure 1. Percentage of antimicrobial resistance Klebsiella pneumoniae

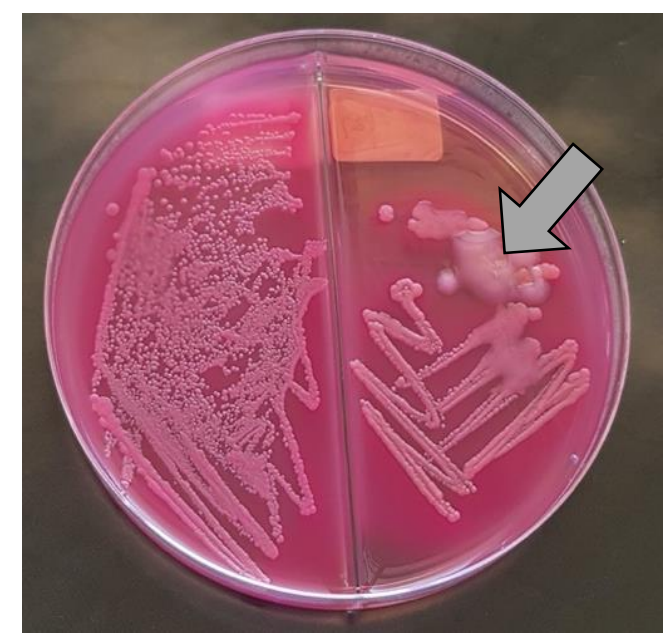

Figure 2. Klebsiella pneumoniae on MacConkey agar; grey arrow is dome-shaped mucoid colony

The presence of multidrug-resistant bacteria is a threat to public health and livestock. These conditions could result in limited treatment options. The only laws on antimicrobial use in food animal production for domestic consumption mandate withdrawal of antimicrobials before processing of food animal products (Brahmachari et al. 2013). Furthermore, multidrug-resistant bacteria triggered the use of an antibiotic that has no longer been used for toxicity, such as colistin (Fard 2004). Measures that could be undertaken were building surveillance programs, conducting surveillance on feed and livestock. Breeders also need to improve biosecurity practice. Evidence indicates that antimicrobial residues in manure might also be responsible for the contamination of soil, surface water, and groundwater resources close to farms involved in intensive broilers rearing activities (FAO 2008). Policy actions should be implemented immediately in order to safeguard the effectiveness of antimicrobials since antimicrobial effectiveness is a globally shared resource and responsibility (Ganguly et al. 2011). Litter and manure waste must be properly managed in intensive production systems to prevent the contamination of air, soil, and water,

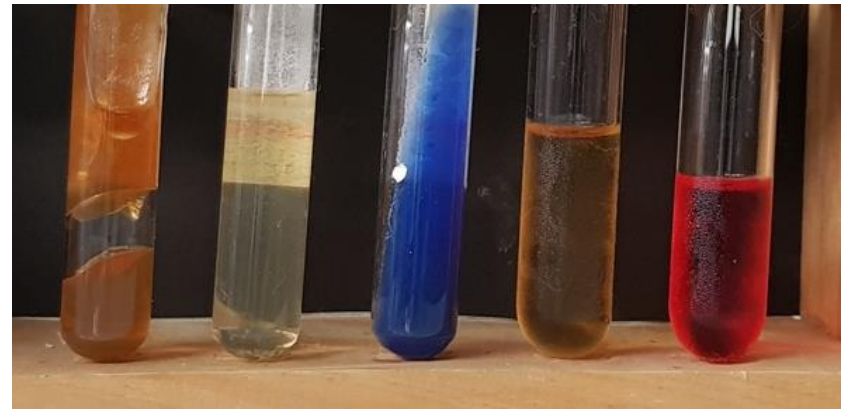

Figure 3. Identification Klebsiella pneumoniae by IMViC and TSIA

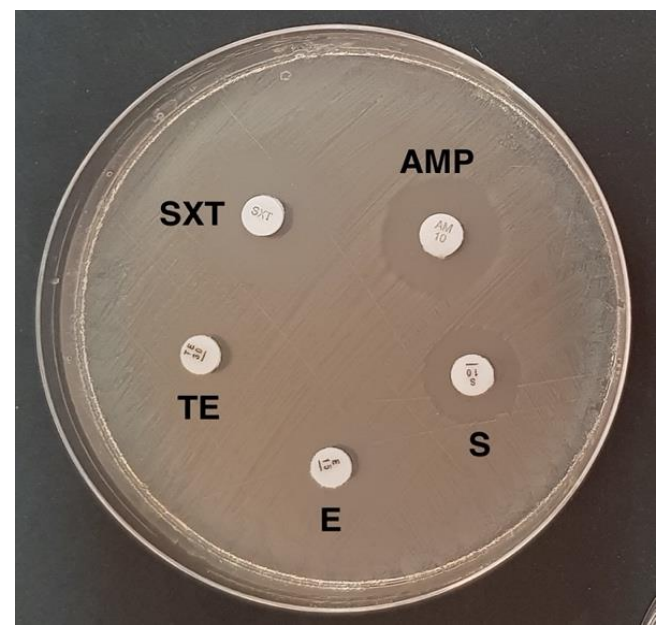

Figure 4. Antibiotic sensitivity confirmation test by disc diffusion by Kirby-Bauer method on Mueller-Hinton agar. Information: ampicillin (AMP), streptomycin (S), tetracycline (TE), erythromycin (E), and sulfamethoxazole (SXT).

as well as negative consequences on human health (Thyagarajan 2014).

The use of antimicrobials in poultry is a well-known catalyst for developing resistance in bacteria (Wibisono et al. 2020), but unfortunately, no reliable data and information are available regarding the use of antimicrobials in poultry (Rahmahani et al. 2020). There is excessive use of antimicrobials in the livestock sector compared to pet animals. The risk of AMR is due to the close association between pet animals and humans and this association provides opportunities for two ways of commensal and pathogenic transfer (Pomba et al. 2017). ESBL is a $\beta$-lactamase that can hydrolyze oxyimino-based $\beta$-lactams, such as cefotaxime, ceftazidime, and aztreonam (Putra et al. 2019). Most K. pneumoniae produce SH-based non-ESBL $\beta$-lactamases such as SHV, and some Escherichia coli produce TEM, which is also a non-ESBL $\beta$-lactamase. Enzymes such as SHV-1 and TEM-1 can hydrolyze ampicillin, but oxyiminocephalosporins including ceftriaxone, cefotaxime, and ceftazidime cannot be hydrolyzed. These antibiotics are well designed to 
counter hydrolysis by these bacterial enzymes (Karanika et al. 2016; Putra et al. 2020).

This study examined the prevalence of resistance in farms suspected of using antimicrobials. Given these limitations, our study mainly compared the resistance profile among different farms (broiler and layer) affecting resistance development. Moreover, it is possible to reduce the prevalence of antimicrobial resistance by placing restrictions on the use of antimicrobials in food animal production without negative impacts on productivity, as evidenced by the experience of both the poultry and pork industries in Denmark (Levy 2014).

In conclusion, this study confirms that the percentage of resistant isolates of $K$. pneumoniae from 5 antimicrobial agents of broiler chicken samples was higher than layer chicken sample. This study also showed highest levels of antibiotic resistance to broiler chicken samples to Ampicillin (AMP) antibiotic. Total of $75 \%$ K. pneumoniae from broiler chicken samples was resistant to Ampicillin (AMP) antibiotic. The presence of multidrug-resistant bacteria is a threat to public health and animals. The impact of these conditions limited and harder the treatment option as chicken farmers in Indonesia still using antibiotics without veterinarian supervision. Policy and veterinarian supervision are important to implement for disease treatment and animal husbandry in Indonesia.

\section{ACKNOWLEDGEMENTS}

This research was in part funded by the Direktorat Riset dan Pengabdian Masyarakat, Deputi Bidang Penguatan Riset dan Pengembangan, Kementerian Riset dan Teknologi/ Badan Riset dan Inovasi Nasional, Indonesia in fiscal year 2020 with grant number: 756/UN3.14/PT/2020 and also the authors would like to thank to Blitar Animal Husbandry for the cooperating.

\section{REFERENCES}

Ahmed OI, Soha AE, Tamer MA, Iman ZA. 2014. Detection of bla SHV and bla CTX-M genes in ESBL producing Klebsiella pneumoniae isolated from Egyptian patients with suspected nosocomial infections. Egypt J Med Hum Genet 14: 277-283. DOI: 10.1016/j.ejmhg.2013.05.002.

Al-Ammiri HH, Abd-Allah AH, Hamid M. 2016. Isolation and identification of aerobic bacteria detected from sheep infected with pneumonia. Adv Environ Biol 10 (5): 214-219.

Arief RA, Darmawan RD, Sunandar, Widyastuti MDW, Nugroho E, Jatikusumah A, Putra AAG, Basuno E, Karuniawati A, Suwandono A, Wiliyanto I, Suandy I, Latif H. 2016. The use of antibiotics in laying hens in Central Java, Indonesia. Konferensi Ilmiah Vet Nasional 14 (1): 22-25. [Indonesian]

Arya LK, Kumar M, Priya P, Saurabh K, Kumari N. 2020. Isolation and identification of Klebsiella pneumoniae from a milk sample. Indian Vet J 97 (1): 15-17.

Brahmachari SK, Misri J, Vijayakumar K, George VI, Chakraborty P, Bhalla S. 2013. Report of the committee on antibiotic use and resistance in food animals. The Public Health Foundation of India, New Delhi, India.

Brower CH, Mandal S, Hayer S, Sran M, Zehra A, Patel SJ, Kaur R, Chatterjee L, Mishra S, Das BR, Singh P, Singh R, Gill JPS, Laxminarayan. 2017. The prevalence of extended-spectrum betalactamase-producing multidrug-resistant Escherichia coli in poultry chickens and variation according to farming practices in Punjab, India. Environ Health Perspect 125 (7): 077015. DOI: 10.1289/EHP292.

CDDEP [Center for Disease Dynamics, Economics \& Policy]. 2015. State of the world's antibiotics, 2015. CDDEP, Washington, DC.

CLSI [Clinical and Laboratory Standards Institute]. 2017. Performance standards for antimicrobial susceptibility testing. 27th eds. CLSI supplement M100. Clinical and Laboratory Standards Institute, Wayne, PA, USA.

Conan A, Goutard FL, Sorn S, Vong S. 2012. Biosecurity measures for backyard poultry in developing countries: a systematic review. BMC Vet Res 8: 240. DOI: 10.1186/1746-6148-8-240.

Davis GS, Price LB. 2016. Recent research examining links among Klebsiella pneumoniae from food, food animals, and human extraintestinal infections. Curr Environ Health 3 (2): 128-135.

Dierikx CM, Van der Goot JA, Smith HE, Kant A, Mevius DJ. 2013. Presence of esbl/ampc -producing Escherichia coli in the broiler production pyramid: a descriptive study. PLoS One 8 (11): e79005. DOI: 10.1371/journal.pone.0079005.

ECDC/EFSA/EMA. 2017. ECDC/EFSA/EMA second joint report on the integrated analysis of the consumption of antimicrobial agents and occurrence of antimicrobial resistance in bacteria from humans and food-producing animals. EFSA J 15: 7.

Effendi MH, Bintari IG, Aksono EB, Hermawan IP. 2018. Detection of blatem gene of Klebsiella pneumoniae isolated from swab of foodproducing animals in East Java. Trop Anim Sci J 41 (3): 174-178.

Effendi MH, Harijani N, Budiarto, Triningtya NP, Tyasningsih W, Plumeriastuti H. 2019. Prevalence of pathogenic Escherichia coli isolated from subclinical mastitis in East Java Province, Indonesia. Indian Vet J 96 (3): 22-25.

Effendi MH, Harijani N, Yanestria SM. Hastutiek P. 2018. Identification of Shiga toxin-producing Escherichia coli in raw milk samples from dairy cows in Surabaya, Indonesia. Philippine J Vet Med 55: 109-114.

El-Mansi M, Anderson KJ, Inche CA, Knowles LK, Platt DJ. 2000. Isolation and curing of the Klebsiella pneumoniae large indigenous plasmid using sodium dodecyl sulphate. Res Microbiol 151: 201-208.

Exner M, Bhattacharya S, Christiansen B, Gebel J, Goroncy-Bermes P, Hartemann P, Heeg P, Ilschner C, Kramer A, Larson E, Merkens W, Mielke M, Oltmanns, Ross B, Rotter M, Schmithausen RM, Sonntag H, Trautmann M. 2017. Antibiotic resistance: what is so special about multidrug-resistant gram-negative bacteria? GMS Hyg Infect Control 12: 5. DOI: $10.3205 /$ dgkh000290.

Fard B. 2004. The effect of colistin sulfate in feed on the controlling of Salmonella enteritidis contamination in a broiler farm. Arch Razi Inst 58 (1): 105-111.

Fielding BC, Mnabisa A, Gouws PA, Morris T. 2012. Antimicrobialresistant Klebsiella species isolated from free-range chicken samples an informal settlement. Arch Med Sci 8 (1): 39-42.

Food and Agriculture Organization. 2008. Poultry production and the environment a review. Animal Production and Health Division, Food and Agriculture Organization of the United Nations, Rome.

Ganguly NK, Arora NK, Chandy SJ, Fairoze MN, Gill JP, Gupta U, Hossain S, Joglekar S, Joshi PC, Kakkar M, Kotwani A, Rattan A, Sudarshan, Thomas K, Wattal C, Easton A, Laxminarayan R. 2011. Rationalizing antibiotic use to limit antibiotic resistance in India. Indian J Med Res 134 (3): 281-294.

Geta K, Kebede A, Chemedissa M. 2019. Antibiotic susceptibility test of bacteria isolated from fruit juices sold in cafes and restaurants of Debre-Markos Town, North Western Ethiopia. World News Nat Sci 24: 365-371.

Guardabassi L, Schwarz S, Lloyd DH. 2004. Pet animals as reservoirs of antimicrobial-resistant bacteria. J Antimicrob Chemother 54 (2): 321332. DOI: $10.1093 / \mathrm{jac} / \mathrm{dkh} 332$.

Hayati M, Indrawati A, Mayasari NLOI, Istiyaningsih I, Atikah N. 2019. Molecular detection of extended-spectrum $\beta$-lactamase-producing Klebsiella pneumoniae isolates of chicken origin from East Java, Indonesia. Vet World 12 (4): 578.

Kar D, Bandyopadhyay S, Bhattacharyya D, Samanta I, Mahanti A, Nanda PK, Mondal B, Dandapat P, Das AK, Dutta TK, Bandyopadhyay S, Singh RK. 2015. Molecular and phylogenetic characterization of multidrug-resistant extended-spectrum betalactamase-producing Escherichia coli isolated from poultry and cattle in Odisha, India. Infect Genet Evol 29: 82-90.

Karanika S, Karantanos T, Arvanitis M, Grigoras C, Mylonakis E. 2016. Fecal colonization with extended-spectrum beta-lactamase-producing Enterobacteriaceae and risk factors among healthy individuals: a 
systematic review and meta-analysis. Clin Infect Dis 63: 310-318. DOI: $10.1093 / \mathrm{cid} / \mathrm{ciw} 283$.

Kempf I, Jouy E, Granier SA, Chauvin C, Sanders P, Salvat G. 2015. Impact of antibiotic use in the swine industry by Mary D. Barton. Curr Opin Microbiol 19: 137-138.

Laube H, Friese A, Salviati CV, Guerra B, Käsbohrer A, Kreienbrock L, Roesler U. 2013. Longitudinal monitoring of extended-spectrum-betalactamase/AmpC- producing Escherichia coli at German broiler chicken fattening farms. Appl Environ Microbiol 79: 4815-4820.

Levy S. 2014. Reduced antibiotic use in livestock: How Denmark tackled resistance. Environ Health Perspect 122 (6): 160-165.

Lynch JP, Clark NM, Zhanel GG. 2013. Evolution of antimicrobial resistance among Enterobacteriaceae (focus on extended-spectrum $\beta$ lactamases and carbapenemases). Expert Opin Pharmacother 14: 199210. DOI: $10.1517 / 14656566.2013 .763030$

Masruroh CA, Sudarwanto MB, Latif H. 2016. The Occurrence of extended-spectrum B-Lactamase-producing Escherichia coli from broiler feces in Bogor. JSV 34: 42-49.

McEwen SA, FedorkaCray PJ. 2002. Antimicrobial use and resistance in animals. Clin Infect Dis 34 Suppl 3: 93-106.

Nahar A, Siddiquee M, Nahar S, Anwar KS, Ali SI, Islam S. 2014 Multidrug-resistant Proteus mirabilis isolated from chicken droppings in commercial poultry farms: Bio-security concern and emerging public health threat in Bangladesh. J Biosafety Health Educ 2: 2. DOI: $10.4172 / 2332-0893.1000120$.

Navon-Venezia S, Kondratyeva K, Carattoli. 2017. Klebsiella pneumoniae: a major worldwide source and shuttle for antibiotic resistance. FEMS Microbiol Rev 41 (3): 252-275.

Okonko IO, Soleye FA, Amusan TA, Ogun AA, Ogunnusi TA, Ejembi J. 2009. Incidence of multi-drug resistance (MDR) organisms in Abeokuta, Southwestern Nigeria. Glob J Pharmacol 3: 69-80.

Pitout JD, Laupland KB. 2008. Extended-spectrum beta-lactamaseproducing Enterobacteriaceae: an emerging public-health concern. Lancet Infect Dis 8 (3): $159-166$. DOI: $10.1016 / \mathrm{S} 1473$ 3099(08)70041-0.

Pomba C, Rantala M, Greko C, Baptiste KE, Catry B, van Duijkeren E. 2017. Public health risk of antimicrobial resistance transfer from companion animals. J Antimicrob Chemother 72: 957-968. DOI: 10.1093/jac/dkw481

Putra AR, Effendi MH, Koesdarto S, Suwarno S, Tyasningsih W, Estoepangesti A.T. 2020. Detection of the extended-spectrum $\beta$ lactamase produced by Escherichia coli from dairy cows by using the Vitek-2 method in Tulungagung regency, Indonesia. Iraqi J Vet Sci 34 (1): 203-207.

Putra ARS, Effendi MH, Koesdarto S, Tyasningsih W. 2019. Molecular identification of Extended-Spectrum Beta-Lactamase (ESBL) producing Escherichia coli isolated from dairy cows in East Java Province, Indonesia. Indian Vet J 96 (10): 26-30.

Rahmahani J, Salamah, Mufasirin, Tyasningsih W, Effendi MH. 2020 Antimicrobial resistance profile of Escherichia coli from cloacal swab of domestic chicken in Surabaya traditional market. Biochem Cell Arch 20 (1): 2993-2997.

Rashed N, Aftab U, Azizul H, Saurab KM, Mrityunjoy A, Majibur R. 2013. Microbiological study of vendor and packed fruit juices locally available in Dhaka city, Bangladesh. Intl Food Res J 20 (2): 10111015 .

Riwu KHP, Effendi MH, Rantam FA. 2020. A review of extendedspectrum $\beta$-Lactamase (ESBL) producing Klebsiella pneumoniae and Multidrug-Resistant (MDR) on companion animals. Syst Rev Pharm 11 (7): 270-277.

Stock I, Wiedemann B. 2001. Natural antibiotic susceptibility of Klebsiella pneumoniae, $K$. oxytoca, K. planticola, K. ornithinolytica and K. terrigena strains. J Med Microbiol 50 (5): 396-406.

Struve C, Bojer M, Krogfelt KA. 2009. Identification of a conserved chromosomal region encoding Klebsiella pneumoniae type 1 and type 3 fimbriae and assessment of the role of fimbriae in pathogenicity. Infect Immun 77 (11): 5016-5024.

Thyagarajan D, Barathi M, Sakthivadivu R. 2014. Risk mitigation of poultry industry pollutants and waste for environmental safety. Glob J Sci Front Res Agric Vet 14 (1): 1-10.

Vasilakopoulou A, Karakosta P, Vourli S, Tarpatzi A, Varda P, Kostoula M, Antoniadou A, Pournaras S. 2020. Gastrointestinal carriage of vancomycin-resistant Enterococci and Carbapenem-resistant gramnegative bacteria in an endemic setting: prevalence, risk factors, and outcomes. Front Public Health 8: 55. DOI: 10.3389/fpubh.2020.00055.

Watts JL. 2013. Performance standards for antimicrobial disk and dilution susceptibility tests for bacteria isolated from animals: Approved Standard. Clinical and Laboratory Standards Institute.

Wibisono FJ, Sumiarto B, Untari T, Effendi MH, Permatasari DA, Witaningrum AM. 2020. Resistance Profile of Extended Spectrum Beta Lactamase-Producing Escherichia coli Bacteria using Vitek® 2 Compact Method. Buletin Peternakan 44 (2): 48-53. [Indonesian]

Wibisono FJ, Sumiarto B, Untari T, Effendi MH, Permatasari DA, Witaningrum AM. 2020. The presence of extended-spectrum betalactamase (ESBL) producing Escherichia coli on layer chicken farms in Blitar Area, Indonesia. Biodiversitas 21 (6): 2667-2671.

Wibisono FJ, Sumiarto B, Untari T, Effendi MH, Permatasari DA, Witaningrum AM. 2020. CTX gene of Extended-Spectrum BetaLactamase (ESBL) producing Escherichia coli on broilers in Blitar, Indonesia. Syst Rev Pharm 11 (7): 396-403.

Widodo A, Effendi H., Khairullah AR. 2020. Extended-spectrum betalactamase (ESBL)-producing Escherichia coli from livestock. Syst Rev Pharm 11 (7): 382-392.

Wu F, Ying Y, Yin M, Jiang Y, Wu C, Qian C, Chen Q, Shen K, Cheng C, Zu L, Li K, Xu T, Bao Q, Lu J. 2019. Molecular characterization of a multidrug-resistant Klebsiella pneumoniae strain R46 isolated from a rabbit. Intl J Genom 2019: 5459190. DOI: $10.1155 / 2019 / 5459190$ 